\title{
The natural history of long-incubation period hepatitis
}

\author{
F. O. MacCALLUM
}

From the Virology Laboratory, the Department of Pathology, The Gibson Laboratories, Radcliffe Infirmary, Oxford

Knowledge of the natural history of long-incubation period hepatitis which has progressed at intervals since 1885 has been expanded to some extent in recent years by the results of tests for hepatitisassociated Australia antigen in the blood of patients with various forms of acute and chronic hepatitis and in apparently healthy individuals in different groups of various populations in different countries. However, advances in our knowledge resulting from this recent discovery have been very small compared with the flood of papers on the subject. In the brief time at my disposal I shall attempt to assess the evidence presented so far of the commonest mode of spread in various situations, and also what uncommon routes are most likely. The degree of infectiousness of the agent or agents and the possible significance of the presence of strains of virus of different infectivity and virulence will also be discussed.

In retrospect, the high rate of infectivity which may occur with injection of very small amounts of blood or tissue fluids was apparent from the first known incident of probable long-incubation period hepatitis in Bremen (Lürman, 1885) when the fluid from vesicles of patients previously vaccinated against smallpox was used to vaccinate 1289 persons by the scratch method; 190 of them developed hepatitis with jaundice. Subsequently groups of cases of jaundice of an apparently similar nature occurred in patients undergoing venepuncture for diagnostic blood tests in some clinics for the treatment of venereal disease and diabetes. In some instances these cases were thought to be related in some manner to catarrhal jaundice which was differentiated from leptospiral jaundice in 1916. However, the first clear indication of the presence of this newly recognized form of blood-transmitted disease occurred in 1937 in the United Kingdom and came from the results of the inoculation of (1) a large pool of adult serum for the prophylaxis of measles in children (MacNalty, 1938; Propert, 1938) and (2) the inoculation of yellow fever vaccine containing a small amount of human serum in adults
(Findlay and MacCallum, 1937). The two common features were that the serum came from apparently healthy donors and that the interval between inoculation and the onset of symptoms or jaundice was two to three months. The value of these observations arose from the fact that single lots of identifiable material were injected into certain people on known dates and that the anti-measles serum contained the bactericidal agents phenol and tricresol, to which the icterogenic agent was obviously resistant. Findlay, MacCallum, and Murgatroyd (1939) suggested that the disease might be caused by a virus and was possibly related to catarrhal jaundice although the incubation period of the latter was thought to be about 20 to 30 days and infection most likely spread by droplets from the upper respiratory tract.

These observations were followed in the periof $1939-45$ by a number of experiments in adult volunteers in Germany, the UK, the USA, and West Africa, and by surveys of the recipients of blood from single donors or pools of plasma in several countries. The results of these showed that there was at least one type of hepatitis virus which might be present in the blood of possibly $1: 100-1: 500$ healthy adults in certain urban centres and that injection of viruscontaining blood by various parenteral routes could produce clinical hepatitis with jaundice in about $50 \%$ of adult recipients after an interval of about two to four months. The results of tests for excess urobilin in the urine and the level of serum bilirubin indicated that in addition subclinical hepatitis might have occurred in a small proportion of the recipients. However, all attempts to transmit the disease by the oral route, which had been successful with blood or faeces from patients with epidemic infectious hepatitis, were apparently unsuccessful.

Because of the concept of droplet spread via the respiratory tract in infectious hepatitis (which has never been proven) this route was investigated in volunteers. Attempts to transmit serum hepatitis by the nasal route by installation of either serum or nasopharyngeal washings from induced cases gave rather peculiar results (Tables I and II). 


\begin{tabular}{|c|c|c|c|c|c|}
\hline Inoculum & Volunteer & Bile in Urine & $\begin{array}{l}\text { Rise in Serum } \\
\text { Bilirubin }\end{array}$ & Symptoms & Jaundice \\
\hline $\begin{array}{l}1.0 \mathrm{ml} \text { serum of one } \\
\text { induced case with long } \\
\text { incubation period } \\
2.0 \mathrm{ml} \text { serum pool }\end{array}$ & $\begin{array}{l}\text { V6 a } \\
\mathrm{b}^{2}\end{array}$ & $\begin{array}{l}39 \\
\text { NT }^{3} \\
\text { NT }\end{array}$ & $\begin{array}{l}24- \\
80-120 \\
87-108\end{array}$ & $\begin{array}{r}36-46 \\
80-130 \\
106-110\end{array}$ & $\begin{array}{l}39-42 \\
80-130 \\
\text { None }\end{array}$ \\
\hline $207 \mathrm{KY}$ & V46 & NT & $54-118$ & None & None \\
\hline
\end{tabular}

Table I Results of intranasal inoculation of serum in adult volunteers (from MacCallum and Bauer, 1944) ${ }^{1}$

${ }^{1}$ In volunteers given $1.0 \mathrm{ml}$ serum of induced case three were negative and no serum was available for tests for Australia antigen. In volunteers given $2.0 \mathrm{ml}$ serum pool $207 \mathrm{KY}$ four volunteers were negative. No particles seen by electron microscopy (1970) but Australia antigen titre $1: 4$ by haemagglutination test in 1971 (courtesy of Dr D. Dane).

${ }^{2} b=$ relapse or second attack Figures $=$ date when biochemical abnormality first detected or duration of symptoms and jaundice in days.

${ }^{3} \mathrm{NT}=$ not tested.

\begin{tabular}{|c|c|c|c|c|}
\hline Inoculum & Volunteer $^{2}$ & $\begin{array}{l}\text { Rise in Serum } \\
\text { Bilirubin }\end{array}$ & Symptoms & Jaundice \\
\hline $\begin{array}{l}\text { Three patients with hepatitis } 80-83 \text { days after } \\
\text { injection with YF vaccine which contained } \\
\text { serum } 207 \mathrm{KY}, 10 \mathrm{ml} \text { washings from each } \\
\text { separately to one volunteer (Findlay and } \\
\text { Martin, 1943) }\end{array}$ & $\begin{array}{l}\text { V1 } \\
\text { V3 } \\
\text { V2 }\end{array}$ & $\begin{array}{l}33 \\
30 \\
57-61\end{array}$ & $\begin{array}{l}30-31 \\
28-29 \\
50\end{array}$ & $\begin{array}{l}0 \\
0 \\
0\end{array}$ \\
\hline $\begin{array}{l}\text { Washings and throat swabs from } 11 \text { donors with } \\
\text { hepatitis induced by arsenotherapy serum } \\
\text { (MacCallum, 1945; MacCallum et al, 1951) }\end{array}$ & $\begin{array}{l}\mathrm{V} 1 \\
\mathrm{~V} 2\end{array}$ & $\begin{array}{l}\text { NT } \\
\text { NT }\end{array}$ & 100 & 100 \\
\hline
\end{tabular}

Table II Results of intranasal inoculation of saline nasopharyngeal washings from patients with long-incubation period hepatitis ${ }^{1}$

${ }^{1}$ All figures relate to the same points as in Table $I$

${ }^{2}$ Fifteen other recipients were negative biochemically and clinically.

Epidemiological studies revealed a very low rate of possible contact cases in uninoculated persons exposed to many thousands of cases of hepatitis induced by contaminated yellow fever vaccine or pools of plasma and also in the contacts of infected volunteers (Table III). Freeman (1946) described four cases of hepatitis in wives of servicemen who had developed the disease after the latter had been injected with the contaminated yellow fever vaccine in the USA but the general conclusion which resulted from a thorough investigation of this large incident (Sawyer, Meyer, Eaton, Bauer, Putnam, and Schwentker, 1944) was that secondary cases were a very rare occurrence. Similarly McFarlan and Chesney (1944) only found six possible secondary cases among 310 uninoculated contacts who were present in a camp at the time of injection of an infected pool of plasma and none in 515 men who arrived in the same large camp a short time after the injection. The two most likely secondary cases among the six were close contacts, presumably in a hut or barracks of three and seven induced cases respectively. These observations, taken together with the failure to transmit infectious, short-incubation period hepatitis by the nasopharyngeal route, resulted in little support for the concept that this route was a natural mode of spread of long-incubation period hepatitis. There has been a tendency in recent years to refer to a much later report of Mirick and Shank (1959) as an example of contact spread by droplet or the faecal/oral route but there are other possible explanations for their observations in that particular incident where $38 \%$ of the service personnel at the involved base were women. The failure to induce obvious hepatitis in adults by oral administration of either icterogenic serum or faeces from patients left the question unsettled of how the agent had maintained itself in the western world for many years before the introduction of syringes, needles, stilettes for blood counts and transfusions, although the transplacental route was considered to be possibly important.

A certain transformation in thought and conception of the mode of spread occurred in 1967 when Krugman, Giles, and Hammond reported that a minor degree of subclinical hepatitis could be detected, by the use of the sensitive serum enzyme tests for abnormal liver function, in a group of mentally retarded children in an institution given long-incubation period hepatitis serum orally, and subsequently in their household contacts. This observation was immediately interpreted by many to mean that the faecal/oral route had been proven as the usual mode of spread, although Krugman and his colleagues did not say this. The introduction of tests for the hepatitis-associated Austrialia antigen made it possible to identify probable cases of sub- 


\begin{tabular}{|c|c|c|c|c|c|c|c|}
\hline \multirow{2}{*}{\multicolumn{2}{|c|}{$\begin{array}{l}\text { Blood } \\
\text { No. }\end{array}$}} & \multirow{3}{*}{$\begin{array}{l}\text { Australia } \\
\text { Antigen }+v e\end{array}$} & \multicolumn{4}{|c|}{ Route of Inoculation } & \multirow{3}{*}{$\begin{array}{l}\text { Contact Cases } \\
\begin{array}{l}\text { One possible case in fellow } \\
\text { resident-number exposed not } \\
\text { known }\end{array}\end{array}$} \\
\hline & & & \multirow{2}{*}{$\begin{array}{l}\text { Intradermal } \\
\text { or Subcutane }\end{array}$} & \multirow{2}{*}{$\begin{array}{l}\text { Intravenous } \\
\begin{array}{l}11 / 19 \\
(46-96) \\
\text { days }\end{array}\end{array}$} & \multirow{2}{*}{\begin{tabular}{|l} 
Oral \\
$0 / 10$
\end{tabular}} & \multirow{2}{*}{$\begin{array}{l}\text { Intranasal } \\
0 / 10\end{array}$} & \\
\hline I & $\begin{array}{l}034 \\
\text { pooled } \\
\text { serum }\end{array}$ & & & & & & \\
\hline II & $\begin{array}{l}207 \mathrm{KY} \\
\text { pooled serum }\end{array}$ & $\begin{array}{l}\text { HA } \\
1: 4\end{array}$ & $\begin{array}{l}5 / 11 \text { vol. } \\
46 / 125 \text { vac. } \\
(56-172) \\
\text { days }\end{array}$ & ND & ND & $\begin{array}{l}1 / 5 \text { (see } \\
\text { Table I) }\end{array}$ & 0 reported \\
\hline III & $\begin{array}{l}\text { Mumps } \\
\text { convalescent } \\
\text { pooled plasma }\end{array}$ & ND & $101 / 266$ & ND & ND & ND & $\begin{array}{l}\text { Six of } 310=4 \text { at } 42-56 \text { days } \\
\text { after inoculation of } 266 \text { men and } \\
\text { occurred at the same time as first } \\
\text { induced cases; two later in } \\
\text { close contacts of three and seven } \\
\text { cases. } \\
0 / 515 \text {-arrivals in camp } \\
\text { subsequent to date of } \\
\text { inoculation }\end{array}$ \\
\hline IV & Saline plasma & ND & $\begin{array}{l}70 \% \text { of } 750 \\
\text { (estimated) }\end{array}$ & ND & ND & ND & $2.6 \%$ of 1455 ( $38 \%$ females) \\
\hline $\mathbf{V}$ & $\begin{array}{l}\text { Track-finders } \\
\text { hepatitis (Sweden) }\end{array}$ & PT & $\begin{array}{l}\text { ?ID } 600 \\
\text { (approximat } \\
\text { no. exposed } \\
\text { known }\end{array}$ & ND & ND & ND & Seven in about 505 households \\
\hline
\end{tabular}

Table III Hepatitis resulting from injection of blood (I-IV) or from presumed entry of blood through skin (V) and secondary cases in contacts

I Bradley et al (1944)

MacCallum et al (1951)

II MacCallum and Bauer (1944)

III McFarlan and Chesney (1944)

IV Mirick and Shank (1959)

V Ringertz and Zetterberg (1967)

$\mathrm{EM}=$ electron microscopy; HA $=$ haemagglutination test (Dr D. S. Dane); PT = precipitin test (Ouchterlony); ${ }^{\circ} 35 / 65$ number of cases/ number injected; vol. = volunteers; vac. = vaccinees; $N D=$ not tested; $I D=$ intradermal.

clinical hepatitis and carriers. It also made it possible to examine stools of patients and carriers for the presence of this marker of serum hepatitis by serological tests and electron microscopy. At present the small number of claims for detection of the antigen in even small amounts in the stools of patients with hepatitis are outnumbered by the failures, although it is possible that minute amounts may be present and detected by concentration of the specimens. I know of only negative results in stools of carriers, including 10 children with Down's syndrome or other mental disease whom we havestudied. Localization of the presence of Australia antigen in the livers of long-incubation period hepatitis by immunofluorescence and electron microscopy has been reported, and two groups of investigators have reported identification of the antigen in bile in a single case so that its presence in the gut might be expected. Information on the infectivity of the urine is also scanty and similar to that on stools although it is obvious that contamination of either faeces or urine with infected blood may render these excreta infective.

Here, then, is a disease of the reticuloendothelial system in which the site(s) of replication of the virus is not known but much the greatest concentration of the agent (about $10^{6}$ or more infective doses) is found in the blood in comparison with that in the excreta.

The blood of people in many types of community who have many different habits and religious and tribal customs has been investigated for the presence of Australia antigen and I believe that it is necessary to consider these groups separately in relation to the questions posed. In most populations in temperate regions, except those living in the most crowded and insanitary conditions, a relatively low prevalence of antigen (1 in 500-1 in 1000 persons) has been found in apparently healthy blood donors (see Table IV). Also a low prevalence of antibody in donors in one region of London has been found recently by Dane (1971) using the sensitive haemagglutination technique. These results were to be expected from the knowledge of the high attack rate $(>50 \%)$ of clinical hepatitis in adults injected with icterogenic pools of serum or single sera from patients with long incubation period hepatitis in the UK in the years 1939-45. With low rates of carriage such as these it is probable that there will also be a relatively low 


\begin{tabular}{|c|c|c|c|}
\hline Country & No. of Donors & Test $^{1}$ & Percentage Positive \\
\hline $\begin{array}{l}\text { Australia } \\
\text { Belgium } \\
\text { Canada } \\
\text { Denmark } \\
\text { France (Paris) } \\
\text { Germany (Freiburg) } \\
\text { Norway } \\
\text { Switzerland } \\
\text { Glasgow } \\
\text { Sheffield } \\
\text { USA, New York } \\
\text { USA, Boston } \\
\text { Japan } \\
\text { Kenya } \\
\text { Sicily } \\
\text { Thailand }\end{array}$ & $\begin{array}{r}56000 \\
6656 \\
257000 \\
10000 \\
18000 \\
2583 \\
3000 \\
2600 \\
106000 \\
60000 \\
85000 \\
51000 \\
5000 \\
200 \\
1133 \\
729\end{array}$ & $\begin{array}{l}\text { IEOP } \\
\text { ID } \\
\text { IEOP } \\
\text { IEOP } \\
\text { ID } \\
\text { IEOP } \\
\text { CFT } \\
\text { ID } \\
\text { ID } \\
\text { IEOP } \\
\text { IEOP } \\
\text { ID } \\
\text { ID } \\
\text { ID } \\
\text { ID } \\
\text { ID } \\
\text { CFT } \\
\text { CFT }\end{array}$ & $\begin{array}{l}0 \cdot 11 \\
0 \cdot 15 \\
0 \cdot 15-0 \cdot 25 \\
0 \cdot 18 \\
0 \cdot 4 \\
0 \cdot 7 \\
4 \cdot 7 \\
0 \cdot 16 \\
0 \cdot 2 \\
0.08 \\
0.07 \\
0.09 \\
0.07 \\
1.03 \\
6 \cdot 0 \\
0.35 \\
5 \cdot 7 \\
10.0\end{array}$ \\
\hline
\end{tabular}

Table IV Prevalence rates of Australia antigen in blood donors

${ }^{1}$ ID $=$ immunodiffusion, CFT = complement-fixation, IEOP $=$ immunoelectroosmophoresis

rate of disease and little or no 'natural' spread in the community other than by direct introduction of blood through the skin or mucous membranes of the mouth and ano-genital regions, mainly in consorts or other very close contacts. In a 12-month period only $5.5 \%$ of 957 patients with acute hepatitis in hospital in the west of Scotland were found to be carrying antigen in their blood by Ross (1971).

The vagina is grossly contaminated with blood five days in every month and transmission to contacts by patients who acquire their antigen during haemodialysis has been found to be $\mathbf{2 0 - 3 0}$ times as frequent in spouses as in other members of the household. Transfer from mother to child as a result of trauma during or shortly after birth has been recorded but transplacental passage, if it occurs, is rare. It is possible that transfer by blood may also occur from unknown carriers in the medical and dental environment apart from that which comes by transfusions or in special units such as those for renal dialysis. Higher rates of carriage and disease may occur in some special groups such as drug addicts within a community with an otherwise low rate of infection.

In populations with a low socio-economic level prevalence of antigenaemia in adults may be low and antibody rates higher than in those of higher social class because of the opportunity for infection at an earlier age. However, under these conditions of infection a larger concentration of virus may be present in excreta at an early age and be transmitted by droplet or by the faecal/oral route which might account for the presence of antigenaemia in a higher proportion of normal donors and patients with chronic hepatitis and cirrhosis in some countries, eg, Greece, Sicily, and Spain.
There have been numerous reports on the high rate of carriage of Australia antigen in mongols in institutions, and, because hepatitis is common among them also, it has been concluded that this supports the idea of faecal/oral spread. However, I believe that confusion has arisen from the way the information has been presented. In the one institution for the mentally retarded which I have investigated in collaboration with Dr H. Phillipson, an epidemic of hepatitis occurred in 1961-62 which involved the inmates of five houses (two for females, two for males, and one for younger members of both sexes, mainly cot and chair cases). The inmates of the two female and two male houses attended school together in the grounds. There were 17 mongols and 36 other mentally retarded males and 16 mongols and 25 other mentally retarded females in these houses and about one third had clinical hepatitis during the epidemic (Table V). No attempt was made to identify subicteric cases. Towards the end of the epidemic, serum was collected from 39 inmates and Australia antigen was found in four out of eight mongol males but in none of the seven mongol girls or 24 other mentally retarded children of either sex (Table VI). When 152 inmates were bled in December 1969 and January 1970 the two surviving Australia antigen-positive males were still carrying antigen in their blood and the blood of six out of 20 other mongol males and three out of 48 other mentally retarded males was positive. None of the 17 mongols and 25 other mentally retarded girls from the house where there were school attenders nor any of the other six mongols and 35 other mentally retarded girls in the other house were positive (Table VI). These results indicate the highly infectious nature of ordinary infectious hepatitis by natural exposure 


\begin{tabular}{|c|c|c|c|c|c|c|}
\hline \multirow[t]{2}{*}{ House } & \multirow[t]{2}{*}{$\operatorname{Sex}$} & \multicolumn{2}{|c|}{ Acute Hepatitis (1961-62) } & \multirow{2}{*}{$\begin{array}{l}\text { School } \\
\text { Attendance }\end{array}$} & \multicolumn{2}{|c|}{ Au Carriage (1969-70) } \\
\hline & & Down's Syndrome & $\begin{array}{l}\text { Other Mentally } \\
\text { Retarded }\end{array}$ & & Down's Syndrome & $\begin{array}{l}\text { Other Mentally } \\
\text { Retarded }\end{array}$ \\
\hline $\begin{array}{l}\text { A } \\
\text { B } \\
\text { C }\end{array}$ & $\begin{array}{l}\mathbf{F} \\
\mathbf{F} \\
\mathbf{M F}\end{array}$ & $\begin{array}{l}8 / 10^{1} \\
2 / 6 \\
1 / 2\end{array}$ & $\begin{array}{l}3 / 6 \\
9 / 19 \\
13 / 23\end{array}$ & $\begin{array}{l}\text { Yes } \\
\text { Yes } \\
\text { No }\end{array}$ & $\begin{array}{l}0 / 12 \\
0 / 5 \\
0 / 2\end{array}$ & $\begin{array}{l}0 / 5 \\
0 / 20 \\
0 / 21\end{array}$ \\
\hline $\begin{array}{l}\text { (Cared } \\
\text { D } \\
\text { E } \\
\text { F } \\
\text { G }\end{array}$ & $\begin{array}{l}\text { grad } \\
\mathbf{M} \\
\mathbf{F} \\
\mathbf{F}\end{array}$ & $\begin{array}{l}\text { m B) } \\
8 / 13 \\
2 / 4 \\
0 / 0 \\
0\end{array}$ & $\begin{array}{l}5 / 12 \\
5 / 22 \\
0 / 26 \\
0\end{array}$ & $\begin{array}{l}\text { Yes } \\
\text { Yes } \\
\text { No } \\
\text { No }\end{array}$ & $\begin{array}{l}7 / 14^{2} \\
1 / 5 \\
0 / 0 \\
0 / 5\end{array}$ & $\begin{array}{l}1 / 11 \\
2 / 19 \\
0 / 20 \\
0 / 13\end{array}$ \\
\hline
\end{tabular}

Table V Epidemic hepatitis and carriage of Australia antigen in children with Down's syndrome and other mentally retarded children in a hospital

${ }^{1}$ Numerator $=$ clinical hepatitis, denominator $=$ number resident

${ }^{2}$ Number with antigen detected by ID, denominator = number tested

\begin{tabular}{lllll}
\hline & Male & & & Female \\
\cline { 2 - 3 } \cline { 5 - 6 } $\begin{array}{l}\text { Down's } \\
\text { Syndrome }\end{array}$ & $\begin{array}{l}\text { Other } \\
\text { Mentally } \\
\text { Retarded }\end{array}$ & $\begin{array}{l}\text { Down's } \\
\text { Syndrome }\end{array}$ & $\begin{array}{l}\text { Other } \\
\text { Mentally } \\
\text { Retarded }\end{array}$ \\
\hline $\begin{array}{l}\text { (Total child population 164) } \\
\text { Negative survivors tested 1969 } \\
0 / 3\end{array}$ & $0 / 15$ & $0 / 7$ & $0 / 9$ \\
Total 1969/70 & $1 / 7$ & & $0 / 4$ & $0 / 7$ \\
& $8 / 20^{1,3}$ & $3 / 48^{4}$ & $0 / 23$ & $0 / 61$ \\
\hline
\end{tabular}

Table VI HAA in Down's syndrome and other mentally retarded children

${ }^{1}$ Numerator $=$ positive in gel diffusion test

2 Two died two years later

sIncludes two positive in 1962, five present but not tested 1962, one arrived after 1962

'One not tested 1962, one arrived after 1962, and one converter.

compared to the relatively non-contagious longincubation period disease in such an institution. The Australia-positive cases among the boys might have resulted from transfer within each house during prophylactic inoculation before the introduction of disposable syringes or by scratches, etc, during play or by other 'natural' means although we have failed to find Australia antigen in the stools of the carriers.

Le Bouvier (1971) and others have reported the presence of three subtypes of Australia antigen and antibody, and preliminary reports suggest that one of these is much commoner than the others in the USA and the UK. By contrast all the positive sera examined from a group of healthy children from the upper Volta in West Africa belonged to the type least common in the USA. However, the exact significance and interrelationship of infection and immunity with the different subtypes has not been ascertained.

A much higher mortality rate has been found in some outbreaks, particularly those associated with units for renal dialysis and kidney transplants: in others there have been no fatalities, although no other apparent difference between the staff and patients in the different centres has been found. Insufficient information is available to relate types of antigen to virulence, but, as in all types of virus infection, the occurrence of mild or unrecognized disease, ie, non-icteric and subclinical hepatitis, favours the maintenance or survival of the antigen (virus).

In summary the data available at the present time indicate to me that the agent or agents of long-incubation period hepatitis are present in the blood of (a) healthy carriers, eg, some donors with no sign of liver disease; $(b)$ affected but symptomless carriers, eg, mongols or other persons with immunological deficiencies. In both situations carriage may persist for many years, possibly a lifetime. It is also, of course, in the blood in the late incubation period and acute stage of hepatitis and sometimes is found in patients with various forms of chronic hepatitis.

The commonest mode of transmission is by transfer of infected blood. This may occur by almost inconceivably small amounts, eg, $0.0001 \mathrm{ml}$ or less through abraided skin or mucous membranes, including during sexual acts and the delivery of babies. The role of arthropods, long considered of possible importance as vectors, particularly in tropical areas, is still unknown.

Although the agent in the serum is highly resistant to heat and drying, the disease is not highly infectious by the 'natural' or usual routes of contagion such as droplets or by the faecal/oral route in the normal population in comparison with infectious hepatitis, measles, mumps, poliomyelitis, and varicella, but it may be infectious for very close contacts such as spouses, sexual partners, mentally retarded persons, and others living in confined quarters, such as service men in barracks or cell mates in prison. (The age at which the antigen is first detected in comparison with the age distribution of infectious 
hepatitis reminds me, to some extent, of the behaviour of type 2 and type 1 herpes viruses).

Very small amounts of the virus may be present in the upper respiratory tract secretions, faeces, and urine. Whether this is free virus from infected cells or the result of contamination with blood remains to be determined.

The role of these secretions and excretions in the spread of the long-incubation period hepatitis virus(es) in various communities in temperate, subtropical, and tropical climates requires more detailed investigation. They may be the source of small doses which produce subclinical infection and the carrier state or the latter without any evidence of tissue (liver) damage. Because of the possible importance of genetic influences, tribal and religious practices, the result of the usual general enquiries regarding socio-economic conditions, season, and climate, which have been so useful in studies of the epidemiology of other virus infections, are by themselves inadequate for the complete understanding of this complex problem.

\section{References}

Bradley, W. H., Loutit, I. F., and Maunsell, K. (1944). An episode of homologous serum jaundice. Brit. med. J., 2, 268-269.

Dane, D. (1971). Personal communication.

Findlay, G. M., and MacCallum, F. O. (1937). Note on acute hepatitis and yellow fever immunization. Tr. roy. Soc. trop. Med. Hyg., 31, 297-308.

Findlay, G. M., MacCallum, F. O., and Murgatroyd, F. (1939). Observations bearing on the aetiology of infective hepatitis (so-called catarrhal jaundice). Trans. roy. Soc. trop. Med. Hyg., 32, 575-586.
Findlay, G. M., and Martin, N. H. (1943). Jaundice following yellowfever immunization: transmission by intranasal instillation. Lancet, 1, 678-680.

Freeman, G. (1946). Epidemiology and incubation period of jaundice following yellow fever vaccination. Amer. J. trop. Med., 26, 15-32.

Krugman, S., Giles, J.P., and Hammond, J. (1967). Infectious hepatitis. Evidence for two distinctvie clinical epidemiological and immunological types of infection. J. Amer. med. Ass., 200, 365373.

Le Bouvier, G. (1971). The heterogeneity of Australia antigen.J.infect. Dis., 123, 671-675.

Lürman, A. (1885). Eine Icterusepidemie. Berl. klin. Wschr., 22, 20-23. MacCallum, F. O. (1945). Transmission of arsenotherapy jaundice by blood. Lancet, 1, 342.

MacCallum, F. I., and Bauer, D. J. (1944). Homologous serum jaundice: transmission experiments with human volunteers. Lancet, 1, 622-627.

MacCallum, F.O., MacFarlan, A.M., Miles, J. A.R, Pollock, M. R., and Wilson, C. (1951). Infective hepatitis: studies in east Anglia during the period 1943-47. Spec. Rep. Ser. med. Res. Coun. (Lond.), 273.

McFarlan, A. M., and Chesney, G. (1944). Hepatitis following injection of mumps convalescent plasma. II. Epidemiology of the hepatitis. Lancet, 1, 816-817.

MacNalty, A. S. (1938). Acute infectious jaundice and administration of measles serum. A.R. med. Off. Minist. Hlth (Lond.), 1937, 38-39.

Mirick, G. S., and Shank, R. E. (1959). An epidemic of serum hepatitis under controlled conditions. Trans. Amer. clin. climat. Ass., 71, 176-190.

Propert, S. A. (1938). Hepatitis after prophylactic serum. (Letter to the Editor). Brit. med. J., 2, 677-678.

Ringertz, O., and Zetterberg, B. (1967). Serum hepatitis among Swedish track-finders: an epidemiologic study. New Engl. J. Med., 276, 540-546.

Ross, C. (1971). Australia antigen and hepatitis in the West of Scotland (September 1970-September 1971). Comm. Dis. Rep. Scotland, 71-37, i-ii.

Sawyer, W. A., Meyer, K. F., Eaton, M.D., Bauer, J. H., Putnam, P., and Schwentker, F (1944). Jaundice in army personnel in the western region of the United States and its relation to vaccination against yellow fever. Pts. II-IV. Amer. J. Hyg., 39, 337-430; 40, 35-107. 